types formed by the metamorphism of rudaceous sedimentary rocks. The above suggested use of the terms psephitic, psammitic, and pelitic, has been adopted in many recent memoirs of the Geological Survey of the United Kingdom, especially those dealing with the gneisses and schists of the northern, north-western, and Grampian Highlands.

\title{
On a Mammoth Molar from North Woodchester, near Stroud.
}

\author{
By Frank Raw, B.Sc., F.G.S.
}

(PLATE X.)

THE tooth, of which a photograph (half-size) is reproduced, was found during Easter, 1916, by the late Mr. W. Harrison, of Selly Oak, Birmingham, who kindly lent it to the writer. Though similar finds are fairly common, this tooth by its form is of rather special interest, and so the writer thinks merits description.

According to the note written down at the time it was received from Mr. Harrison, it was found "at North Woodchester, at the base of the hill that rises to Selsley Hill". This village is about $1_{4}^{3}$ miles S.S.W. of Stroud, Gloncestershire, on the west side of the valley that runs here behind the edge of the Cotteswolds, of which Selsley Hill forms a part. North Woodchester lies along the road that runs west from the bottom of this vallev (perhaps 150 feet O.D.). and rises to Selsley Hill (689 feet). The range in height of the village is from 200 feet O.D. to 300 feet O.D., and from the description of the site by Mrs. Harrison the writer judges the altitude of the find to be about 300 feet O.D.

The tooth was found in a gravel pit, the gravel consisting largely of Oolitic and Liassic debris. Terebratula globata, fragments of Belemnites, and Ammonites serpentinus were recognized by the writer among the material collected from it by Mr. Harrison. As North Woodchester, according to the Geological Map, lies on Upper Lias, it may be concluded that the deposit of gravel lies on this formation, whence was derived Ammonites serpentinus and probably the Belemnites. Selsley Hill is of Inferior Oolite, which also forms the high ground to the east and covers a large area to the north.

Mammoth remains seem fairly common in these gravels near Stroud. W. C. Lucy in $1869^{1}$ records the occurrence of remains of the mammoth, woolly rhinoceros, reindeer, and bison (Bos primigenius) in Gannicox Pit, Stroud, as well as land and freshwater snails from lenticles of clay interstratified with the gravel. Mr. Edwin Witchell, ${ }^{2}$ who had discovered these fossil shells, describes the gravels and their fossil contents, mentioning "fine tusks of the mammoth

1 W. C. Lucy, " The gravels of the Serern, Avon, and Evenlode, and their extension over the Cotteswold Hills": Proc. Cottes. Nat. F.C., vol, v, 1869.

3 E. Witchell, The Geolog!" of Strout. Also Stroud Nat. Hist. and Prill. Soc., 1876-8. Proc. Cottes. Nat. F.C., vol. viii, 1883. 
and teeth of the woolly rhinoceros and reindeer". He states that "there is an absence of marine or estuarine shells in these gravels", and that "it is therefore probable that the whole of these gravels are of fresh-water origin, and were the drifts and breakers of a lake which once occupied the valley of the Severn". The writer knows of no facts militating against this conclusion. Mr. L. Richardson, ${ }^{1}$ in a report of a visit of the Cotteswold Club to the Gannicox and Cainscross gravel pits near Stroud, in the course of a useful summary of what was known of the fossil contents of the gravels, gives a list of thirteen species of land and freshwater shells obtained by Witchell from clayey seams in the gravels, not one of which is a marine species.

The assemblage of mammalia is of glacial character and points to a time near that of the "Würm " glaciation, the last of the major glaciations established by Penck and Briickner in the Alps, and coinciding with the formation of the "Newer Drift" of the North European plain. It was there that the mammoth was most numerous, though its remains are fairly common in deposits of the earlier "Riss" glaciation. Mammoth remains are also recorded from a consideralfie number of places in and around the Cotteswolds. It is generally agreed that there was no glaciation of the Cotteswolds, which were too high to be overflowed, but not high enough to nourish glaciers of their own, and the writer imagines that herds of mammoths roamed over the area, while the Welsh mountains, perhaps at that time higher relatively than now, owing to an uptilt of the country to the west, shed extensive glaciers across the estuary of the Severn, and by damming back the waters formed a lake, to the fluctuating levels of which the Cotteswold streams built deltas, but to quote Mr. Richardson," "more work is necessary" (and the writer has done none) "before any suggestion of value can be made."

\section{Description of the ToOth.}

The tooth measures 8 inches in length, by $4 \frac{1}{2}$ incbes deep, by $2 \frac{3}{4}$ inches wide, the photograph being half natural size. In shape it closely resembles a yacht, the worn surface of the tooth corresponding to the deck of the ship; but the front of the yacht is seen in the posterior end of the tooth and vice versa.

The lateral aspect is about equally divided between the complexly folded broad crown and the narrower "keel", the depth of crown and keel being about equal to one another in the different parts of the length. The worn surface being oblique, one lateral aspect (the outer) has less crown than the other.

The superior aspect is entirely occupied with the grinding surface, which, though nearly flat, is obliquely concave. This measures $7 \frac{1}{4}$ by $2 \frac{3}{4}$ inches. All the tooth folds or "plates" that remain are worn, the keel being only 1 inch below the posterior border,

1 L. Richardson, Proc. Cottes. Nat. F.C., vol. xviii, 1914, pt. iii, p. 205.

2 L. Richardson, "Pxcursion to Sttoud": Proc. Cottes. Nat. F.C., 1914, p. 205 . 
while in front the grinding surface cuts across the base of the crown, exhibiting the bottom of an enamel infold. Twelve plates are evidenced together with a talon behind, but it is impossible to say how many have been ground away entirely in front.

The curved shape of the base of the crown and its relative shallowness indicate that this is a lower molar, and since when looked at from above the plates run obliquely forward to the left, it is seen to belong to the right side of the mandible.

Posteriorly the crown narrows like the prow of a ship to a relatively fine edge, and thus gives no suggestion of pressure being exerted through a tooth following it in the jaw. This would indicate that it is the last tooth or third true molar. Its characters thus indicate an ultimate right lower molar.

For specific determination of such teeth reliance is placed on the form and spacing of the "plates" and the thickness and form of the enamel layers as seen in section on the grinding surface. In the Woodchester specimen the plates are closely spaced and the dentine and cement are in parallel bands and almost exactly equal to one another, but the posterior plates are drawn forward and constricted near their middle. The closeness of the plates is indicated by the length of tooth for a definite number of plates. There are ten complete folds in $5 \cdot 75$ to 6 inches or eight full size in $4 \cdot 6$ inches. The enamel is about $\cdot 06$ in. thick, is crimped, and especially throughout the posterior half of the tooth forms compressed outfolds on the plates. These characters taken all together indicate Elephas primigenius or the Mammoth, though each of these characters could without doubt be matched among teeth ascribed to Elephas antiquus. According to Dr. Adams ${ }^{1}$ the number of plates, not counting the talon or heel at each end in the last molars of the mammoth ranges from 18 or 19 to 27 , the width from 2 to $4 \frac{1}{2}$ inches, the closeness of the plates from eight plates in $5 \mathrm{in}$. to the same number in $3 \cdot 1 \mathrm{in}$. In our tooth the measures given above of width ( $2 \frac{3}{4}$ in.), and closeness of plates (eight in 4.6 in.), fall well witbin this range. But as already noted detrition here is very far advanced, the remaining portion of the crown varying from 1 in. deep behind, through 2 in. at its deepest, to 0 in. in front and so the number of plates is quite unknown. And as the commonest number of plates in these teeth is probably 22 or 23 , the plates at the anterior end which are worn right away to the base are the middle ones of the entire tooth. Thus the superior surface probably measured originally $14 \mathrm{in}$. or $15 \mathrm{in}$. by $2_{i}^{3} \mathrm{in}$., while we may take the original depth of the crown as probably 4 in. or $4 \frac{1}{2}$ in. The animal was thus in advanced old age, and had worn away all but one-sixth or one-eighth of the volume of the crown of its last teeth.

Moreover, the occurrence of a continuous keel below the erown in place of a number of fangs seems to be characteristic of the last part

1 A. Leith Adan!s, "British Fossil F.lephants" : Palaoontographical Society, $1877-81$, p. 125. 


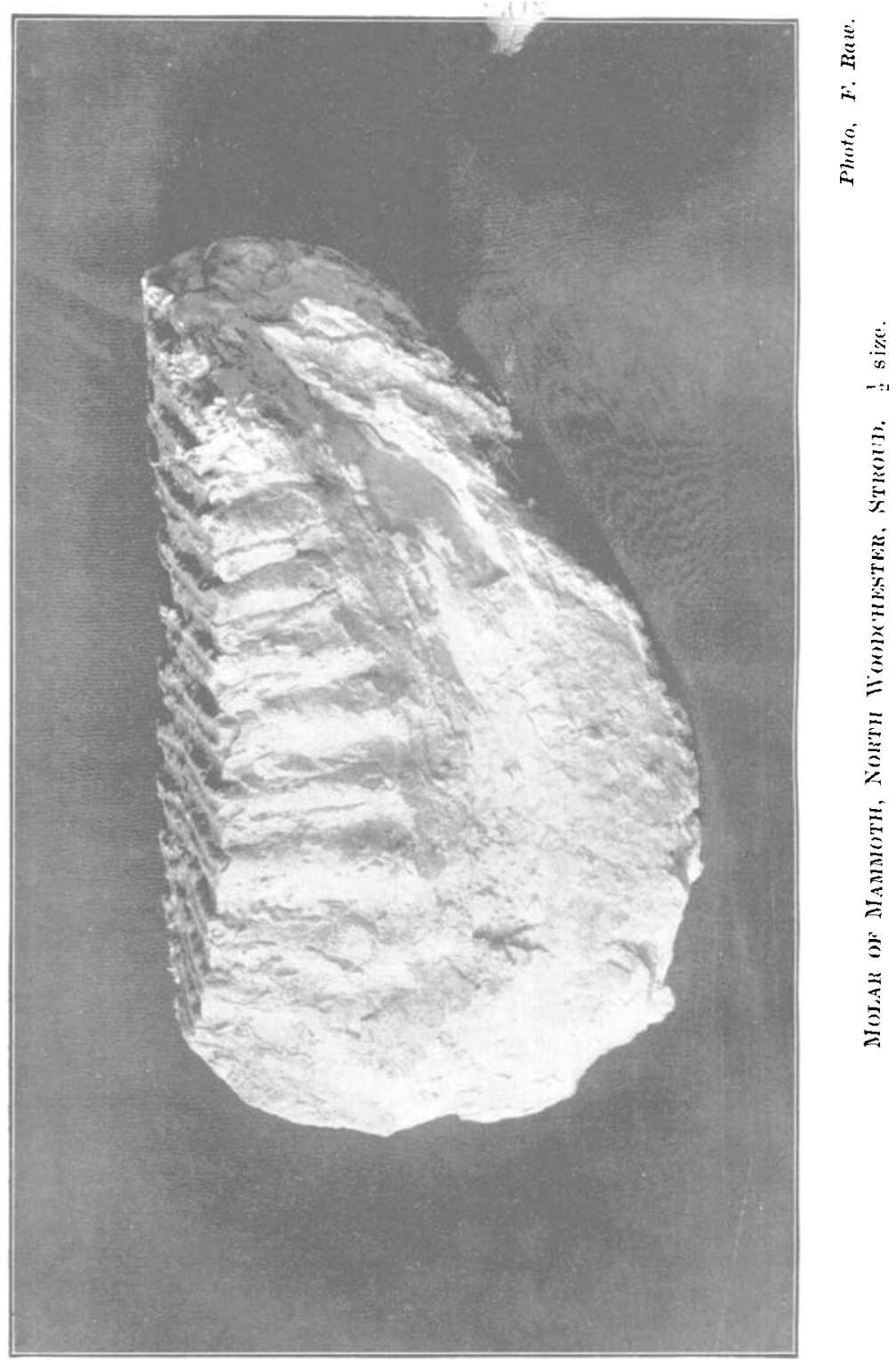

Facing p. 50.5.] 
of the last tooth and part of the arrangement for pushing it up into a working position in the absence of pressure from behind. Mr. Adams (loc. cit., p. 1 describing a much detrited last lower molar in the Woodwardian useum, says: "The fangs had become consolidated into a ridge like the keel of a vessel "-an exactly similar condition to that here displayed. This character may thus be taken as confirming the conclusion otherwise arrived at that this is an ultimate molar. For a microscopis examination of the substance of the keel the writer is indebted to Mr. W. Courtney Iyne, who identifies it as dentine, which normally composes the fangs.

Compared with last lower molars of the mammoth described by Mr. Adams (loc. cit.), and with the fragments in the Birmingham Vniversity Geological Museum, this is rather a narrow tooth, but the measures of several narrower are given in the work referred to. On the other hand, judging by what remains, it would, when complete, be fully as long as the complete molars there described, but these from their very completeness are probably for the most part smaller than the average. It is, indeed, by no means as large in any dimension as they often attain.

The tooth is in a good state of preservation, the grinding surface, though much cracked, preserving the original relief and a fair degree of polish on the enamel. But at the sides of the crown the cement has in places fallen away as has also dentine from the keel. It exhibits no effects of water-wear and so cannot have been carried by water far from the mandible and the skull. There is every probability, therefore, of more mammoth remains having been entombed in the neighbouring gravel.

The tooth is in the possession of Mr. Harrison's widow, to whom the writer is deeply indebted for an extended loan of the specimen and for information regarding the position of the find.

EXPLANATION OF PLATE $X$.

Photegraph of ultimate right lower Molar of Mammoth found at North Wocdchester, near Stroud, by the late Mr. W. Harrison, of Selly Oak, Birmingham, Easter, 1916. Photo-half natural size.

\section{The Primary Zones of Cornish Lodes}

By E. H. Darison, B.Sc., F.G.S.

D URING the last two and a half years I have been engaged in the study of the Cornish Veinstones in the field and in the laboratory by microscopic and other methods, and have come to the following conolusions:--

That, as recognized by many observers, the primary minerals of Cornish lodes occur in zones which change their character in depth ; thus copper minerals give place to cassiterite on passing down the lode and chlorite gives place to tourmaline.

From observations on over 150 lodes in more than 100 different mines, taken on the spot or abstracted from old records, in and 